\title{
Keberhasilan hidup parasitoid Diadegma semiclausum Hellen dan serangga inangnya Plutella xylostella (L.) terhadap aplikasi ekstrak biji srikaya (Annona squamosa L.)
}

\author{
Survival of parasitoid Diadegma semiclausum Hellen and its host, \\ Plutella xylostella (L.) after aplication of sugar apple seed extract \\ (Annona squamosa L.)
}

Bonjok Istiaji*, Djoko Prijono, Damayanti Buchori

Departemen Proteksi Tanaman, Fakultas Pertanian, Institut Pertanian Bogor Jalan Kamper, Kampus IPB Dramaga, Bogor 16680

(diterima April 2017, disetujui Maret 2018)

\begin{abstract}
ABSTRAK
Pengendalian Plutella xylostella L. dapat dilakukan baik secara hayati maupun kimiawi. Pengendalian secara hayati umumnya banyak dilakukan dengan cara memanfaatkan ekstrak tanaman untuk membunuh serangga hama. Penelitian ini bertujuan mengetahui pengaruh ekstrak biji srikaya terhadap kematian dan perkembangan parasitoid Diadegma semiclausum Hellen serta inangnya, P. xylostella. Pengaruh ekstrak biji srikaya terhadap larva P. xylostella instar III awal diuji dengan metode residu pada daun dan metode residu pada permukaan gelas untuk menguji pengaruh kontak ekstrak biji srikaya terhadap kematian imago $D$. semiclausum. Pengaruh ekstrak biji srikaya terhadap parasitisasi dan perkembangan $D$. semiclausum pradewasa dilakukan dengan memaparkan larva $P$. xylostella yang telah terkontaminasi ekstrak biji srikaya pada konsentrasi subletal $\left(\mathrm{LC}_{5}\right.$ dan $\left.\mathrm{LC}_{10}\right)$ pada imago D. semiclausum. Hasil penelitian menunjukkan ekstrak biji srikaya pada konsentrasi $0,0632-0,1 \%$ pada kontaminasi 24 jam berpengaruh terhadap kematian larva P. xylostella dan imago parasitoid $D$. semiclausum. Imago parasitoid lebih peka terhadap peningkatan konsentrasi ekstrak biji srikaya dibandingkan dengan larva $P$. xylostella. Hambatan perkembangan P. xylostella oleh ekstrak biji srikaya pada konsentrasi yang digunakan umumnya tidak nyata. Demikian pula, hambatannya terhadap perkembangan parasitoid $D$. semiclausum dalam inang yang terkontaminasi konsentrasi subletal $\left(\mathrm{LC}_{5}\right.$ dan $\mathrm{LC}_{10}$ ) ekstrak biji srikaya umumnya tidak berbeda nyata. Keberadaan ekstrak biji srikaya dalam inang juga tidak berpengaruh nyata terhadap tingkat parasitisasi, panjang kokon, lebar kokon, dan bobot kokon. Oleh karena itu, terdapat peluang memadukan pengendalian P. xylostella secara kimiawi dan hayati.
\end{abstract}

Kata kunci: insektisida botani, pengendalian hayati, subletal

\begin{abstract}
Control of Plutella xylostella L. can be done both biologically and chemically. Biological control is generally done by utilizing plant extracts to kill insect pests. This study aims to determine the effect of the extract of seeds on the mortality and development of parasitoid Diadegma semiclausum Hellen and its host, P. xylostella. The effect of Srikaya seed extract on P. xylostella larvae in the initial stage was tested by foliar rest method, while the residue method on the glass surface was used to test the effect of the extract of seed extract of Srikaya on the death of imago D. semiclausum.
\end{abstract}

\footnotetext{
*Penulis korespondensi: Bonjok Istiaji. Departemen Proteksi Tanaman, Fakultas Pertanian, Institut Pertanian Bogor Jalan Kamper, Kampus IPB Dramaga, Bogor 16680, Email: bistiaji@ipb.ac.id, Faks/Tel: 0251-8423779
} 
The effect of seed extract on parasitization and development of $D$. semiclausum was performed by exposing P. xylostella larvae contaminated by the extract of srikaya seeds in sublethal concentration $\left(\mathrm{LC}_{5}\right.$ and $\left.\mathrm{LC}_{10}\right)$ in imago D. semiclausum. The results showed that extract of srikaya seeds at a concentration of $0.0632-0.1 \%$ at 24 -hour contamination affected the death of the larva P. xylostella and the imago parasitoids $D$. semiclausum. Imago parasitoids are more susceptible to increased concentration of extracts than $P$. xylostella larvae. The developmental resistance of $P$. xylostella by Srikaya seed extract at concentrations used is generally unreal. Similarly, the barriers to the development of parasitoid $D$. semiclausum in hosts contaminated with sublethal concentrations ( LC $_{5}$ and $\mathrm{LC}_{10}$ ) of seed extract are generally not significantly different. The presence of Srikaya seed extract in the host also has no significant effect on the extent of parasitization, cocoon length, cocoon width, and cocoon weight. Therefore, there is a possibility to chemically and biologically integrate P. xylostella control.

Key words: biological control, botanical insecticides, sublethal

\section{PENDAHULUAN}

Plutella xylostella (L.) (Lepidoptera: Yponomeutidae) adalah hama utama tanaman kubis yang tersebar di seluruh dunia (Ahmad et al. 2015; Sarfraz et al. 2005). Kerusakan tanaman akibat serangan hama ini bisa mencapai $100 \%$ bila tidak ada usaha pengendalian sama sekali (Kalshoven 1981)

Ada beberapa cara pengendalian P. xylostella, diantaranya ialah pengendalian secara hayati maupun kimiawi. Dalam lingkup pengendalian hayati, Diadegma semiclausum Hellen (Hymenoptera: Ichneumonidae) memiliki peran penting. Menurut Sastrosiswojo \& Sastrodihardjo (1986), tingkat parasitisasi P. xylostella oleh $D$. semiclausum di Indonesia mencapai $80 \%$ bila insektisida tidak digunakan. Dalam pengendalian kimiawi, penggunaan insektisida sering melebihi dosis yang dianjurkan. Akibatnya, P. xylostella menjadi salah satu spesies yang paling banyak dilaporkan resisten terhadap pestisida (Idris \& Grafius 1993b; Iman et al. 1986; Agboyi et al. 2016).

Sejalan dengan perkembangan pertanian yang ramah lingkungan, usaha mengganti insektisida sintetik mulai dilaksanakan (Oberemok et al. 2015). Salah satu pilihannya adalah pemanfaatan insektisida botani (insektisida nabati). Insektisida botani diperkirakan relatif aman bagi lingkungan karena persistensinya rendah (Prijono \& Triwidodo 1994; Mpumi et al. 2016). Salah satu sumber insektisida botani adalah tanaman srikaya (Annona squamosa L.). Srikaya dilaporkan mempunyai pengaruh merugikan (insektisida, menghambat makan, menghambat pertumbuhan) terhadap beberapa jenis serangga hama (Ohsawa et al. 1994; Setiowati 1995; Supriyanto 1996; Isman \& Seffrin 2014). Keefektifan ekstrak biji dan akar srikaya terhadap $P$. xylostella dilaporkan dalam Rejesus (1986). Keefektifan ekstrak kasar bahan tumbuhan bergantung pada kandungan senyawa aktif insektisidanya, yang dapat dipengaruhi oleh faktor geografi.

Kesesuaian antara cara pengendalian hayati dan kimiawi merupakan tuntutan yang harus dipenuhi (Orr 2009). Sebelum direkomendasikan untuk mengendalikan P. xylostella, perlu diketahui pengaruh residu senyawa aktif srikaya terhadap $D$. semiclausum. Idris \& Grafius (1993a) melaporkan insektisida dengan bahan aktif permetrin dan azinfosmetil mematikan imago Diadegma insulare (Cresson), tetapi tidak mematikan larva $P$. xylostella.

Ada beberapa pengaruh yang dapat ditimbulkan senyawa sekunder srikaya terhadap parasitoid, yaitu pengaruh kontak terhadap imago parasitoid dan pengaruh penghambatan perkembangan larva $D$. semiclausum di dalam tubuh serangga inang ( $P$. xylostella). Pengaruh kontak terhadap imago $D$. semiclausum dapat terjadi mengingat habitat parasitoid sama dengan larva $P$. xylostella. Gerakan D. semiclausum lebih aktif dibandingkan dengan larva $P$. xylostella sehingga peluang kontak dengan residu senyawa aktif srikaya lebih besar. Rendahnya persistensi insektisida botani justru berpeluang menjadi penyebab timbulnya dampak negatif senyawa sekunder srikaya terhadap larva D. semiclausum. Karena mudah terurai, suatu saat senyawa aktif srikaya dapat mencapai dosis subletal bagi serangga sasaran. Artinya, P. xylostella masih mampu bertahan hidup walaupun tubuhnya mengandung residu senyawa 
sekunder srikaya. Keberadaan senyawa sekunder tersebut dapat bermakna penurunan kualitas inang sehingga perkembangan larva $D$. semiclausum mungkin terhambat. Penelitian ini bertujuan untuk mengetahui pengaruh ekstrak biji srikaya terhadap kematian dan perkembangan parasitoid D. semiclausum serta inangnya, $P$. xylostella.

\section{BAHAN DAN METODE}

\section{Ekstraksi biji srikaya}

Biji srikaya diperoleh dari Kabupaten Cirebon, Jawa Barat. Biji srikaya yang digunakan adalah biji yang berwama hitam dan berasal dari buah yang telah masak. Biji dikeringudarakan dan kemudian dikupas kulit bijinya. Biji srikaya yang telah bersih dihancurkan dengan blender dan diayak dengan pengayak berukuran $\leq 0,5 \mathrm{~mm}$ sehingga diperoleh serbuk biji srikaya.

Ekstrak biji srikaya diperoleh dengan cara maserasi. Serbuk biji srikaya disuspensikan dalam metanol dengan perbandingan $10 \mathrm{ml}$ metanol untuk setiap gram serbuk. Suspensi diaduk dengan pengaduk magnit selama 24 jam untuk mempercepat kelarutan bahan yang akan diekstrak dalam metanol. Selanjutnya, dilakukan penyaringan dengan kertas saring Whatman No. 41. Ekstrak biji srikaya dipisahkan dari pelarutnya dengan menguapkan filtrat mengunakan (rotary evaporator). Hasil akhir proses ini adalah ekstrak kasar berupa cairan pekat dan padatan berwama coklat.

\section{Pemeliharaan $P$. xylostella}

Serangga uji $P$. xylostella berasal dari daerah Puncak, Jawa Barat dan diperbanyak di Laboratorium Pengendalian Hayati, Jurusan Hama dan Penyakit Tumbuhan, Fakultas Pertanian, Institut Pertanian Bogor.

Imago $P$. xylostella dipelihara dalam kurungan kain kasa berangka kayu $(40 \mathrm{~cm}$ x $40 \mathrm{~cm}$ x $40 \mathrm{~cm}$ ). Di dalam kurungan diletakkan daun brokoli sebagai tempat peletakan telur serangga. Setiap dua hari sekali daun diganti dan daun yang mengandung telur diletakkan dalam kotak pemeliharaan larva. Imago diberi pakan larutan madu $10 \%$ yang diserapkan pada segumpal kapas. Larva P. xylostella dipelihara dalam kotak plastik
( $35 \mathrm{~cm} \times 25 \mathrm{~cm} \times 7 \mathrm{~cm}$ ) berjendela kasa dan di beri pakan daun brokoli bebas pestisida.

\section{Pemeliharaan parasitoid $D$. semiclausum}

Pupa D. semiclausum dikumpulkan dari lokasi yang sama dengan P. xylostella. Pupa ini ditempatkan dalam kotak yang serupa dengan kotak pemeliharaan larva $P$. xylostella. Imago parasitoid D. semiclausum yang berhasil keluar dari kokon dipindahkan ke tempat pemeliharaan berbentuk tabung plastik bening $(\mathrm{d}=10 \mathrm{~cm}$ dan $\mathrm{t}=25 \mathrm{~cm})$ dan diberi pakan larutan madu $10 \%$.

Di dalam tabung ditempatkan larva $P$. xylostella instar III dengan perbandingan 20 individu larva inang untuk satu parasitoid betina. Pemaparan inang dilakukan selama 24 jam, setelah itu parasitoid dipisahkan dari kurungan dan diberi larva inang yang baru. Larva inang yang terparasit dipelihara hingga terbentuk imago parasitoid. Imago D. semiclausum yang berasal dari lapang maupun dari pemeliharaan di laboratorium digunakan sebagai serangga uji.

\section{Pengujian pengaruh ekstrak biji srikaya terhadap larva $P$. xylostella}

Percobaan disusun dalam rancangan acak lengkap dengan beberapa konsentrasi untuk pengujian pengaruh ekstrak biji srikaya terhadap larva P. xylostella.

Ekstrak biji srikaya diuji pada enam taraf konsentrasi yang diharapkan dapat menyebabkan kematian serangga uji lebih dari $0 \%$ dan kurang dari $100 \%$, yang ditentukan berdasarkan uji pendahuluan. Perlakuan pakan (feeding method) dengan lama pemberian pakan, yaitu 6, 9, 12, dan 24 jam. Konsentrasi ekstrak yang digunakan pada perlakuan kontaminasi 6 jam adalah $0,02 \%$, $0,032 \%, 0,0504 \%, 0,08 \%, 0,1264 \%$, dan $0,2 \%$. Kontaminasi 9 jam menggunakan konsentrasi $0,0175 \%, 0,0028 \%, 0,0441 \%, 0,07 \%, 0,1106 \%$, dan $0,175 \%$. Kontaminasi 12 jam menggunakan konsentrasi $0,015 \%, 0,024 \%, 0,038 \%, 0,06 \%$, $0,0948 \%$, dan $0,15 \%$, dan kontarminasi 24 jam menggunakan konsentrasi $0,01 \%, \quad 0,016 \%$, $0,0252 \%, 0,04 \%, 0,0632 \%$, dan $0,1 \%$.

Pengujian dilakukan menggunakan metode residu pada daun. Ekstrak biji srikaya yang telah ditimbang bobotnya dilarutkan dalam metanol dan pengemulsi Latron 77 (konsentrasi akhir 
masing-masing 5\% dan 0,2\%) lalu ditambah air suling hingga volume tertentu sesuai dengan konsentrasi pengujian. Sebagai kontrol digunakan air suling yang mengandung $5 \%$ metanol dan $0,2 \%$ pengemulsi.

Potongan daun brokoli tanpa pestisida berukuran $3 \mathrm{~cm}$ x $3 \mathrm{~cm}$ dicelupkan dalam larutan uji selama 5 detik sampai basah merata dan lalu dikeringanginkan. Sepuluh instar III P. xylostella yang baru ganti kulit diletakkan di dalam cawan petri berdiameter $9 \mathrm{~cm}$ yang dialasi kertas saring, lalu larva diberikan pakan daun brokoli perlakuan sesuai konsentrasi dan dibiarkan makan selama waktu kontaminasi tertentu. Setelah melewati waktu kontaminasi tersebut, daun brokoli diganti dengan daun tanpa perlakuan. Setiap perlakuan diulang empat kali.

Data tingkat kematian larva diamati setiap hari hingga seluruh larva menjadi imago atau semua larva mati.

Pengujian pengaruh kontak residu ekstrak biji srikaya terhadap imago parasitoid $D$. semiclausum

Percobaan disusun dalam rancangan acak lengkap dengan beberapa konsentrasi untuk pengujian pengaruh kontak residu ekstrak biji srikaya terhadap imago parasitoid D. semiclausum.

Pengujian residu ekstrak biji srikaya terhadap imago parasitoid $D$. semiclausum dilakukan dengan metode kontak dan larutan uji dibuat dengan cara yang sama dengan perlakuan pengaruh ekstrak terhadap larva $P$. xylostella. Konsentrasi ekstrak yang digunakan adalah $0,01 \%, 0,016 \%$, $0,0252 \%, 0,04 \%, 0,0632 \%$, dan $0,1 \%$ atau sama dengan konsentrasi untuk pengujian pengaruh ekstrak terhadap larva $P$. xylostella pada taraf lama kontaminasi 24 jam. Setiap perlakuan diulang empat kali.

Larutan uji dioleskan secara merata ke dalam tabung reaksi $(\mathrm{d}=2 \mathrm{~cm}$ dan $\mathrm{t}=15 \mathrm{~cm})$ menggunakan kuas dan didiamkan hingga larutan uji yang dioleskan kering. Sebagai pakan serangga uji, madu diteteskan di dalam tabung reaksi sebelum diolesi larutan uji. Sepuluh imago $D$. semiclausum betina yang baru keluar dari kokon dimasukkan ke dalam tabung dan didiamkan selama dua puluh empat jam, kemudian imago dipindahkan ke dalam tabung yang bersih dan dicatat kematiannya setiap hari hingga hari ke-7.
Pengujian pengaruh ekstrak biji srikaya dalam tubuh inang $P$. xylostella terhadap parasitoid $D$. semiclausum

Pengujian pengaruh ekstrak biji srikaya dalam tubuh inang $P$. xylostella terhadap parasitoid $D$. semiclausum menggunakan rancangan faktorial dengan faktor konsentrasi ekstrak dan lama waktu kontaminasi.

Untuk mendapatkan inang P. xylostella yang terkontaminasi ekstrak biji srikaya dalam jaringan tubuhnya, dilakukan perlakuan metode residu pada daun, seperti dijelaskan pada bagian sebelumnya. Dua taraf konsentrasi yang dapat menyebabkan peluang kematian larva $P$. xylostella sebesar $5 \%$ dan $10 \%\left(\mathrm{LC}_{5}\right.$ dan $\left.\mathrm{LC}_{10}\right)$ digunakan dalam perlakuan. Pengujian ini dilakukan dalam tiga taraf lama pemberian pakan/ kontaminasi, yaitu 6, 12, dan 24 jam. $\mathrm{LC}_{5}$ dan $\mathrm{LC}_{10}$ untuk kontaminasi 6 jam adalah $0,0274 \%$ dan $0,0389 \%$, kontaminasi 12 jam adalah $0,0101 \%$, dan $0,0156 \%$ serta kontaminasi 24 jam adalah $0,0041 \%$ dan $0,0059 \%$. Pengujian dilakukan dalam 10 ulangan atau lebih dan masing-masing pengujian disertai kontrol.

Lima belas larva $P$. xylostella yang telah terkontaminasi ekstrak biji srikaya diletakkan ke daun brokoli di dalam kurungan plastik berbentuk silinder $(\mathrm{d}=10 \mathrm{~cm}$ dan $\mathrm{t}=25 \mathrm{~cm})$. Ke dalam setiap kurungan dimasukkan satu imago parasitoid betina berumur 3-5 hari yang telah dikawinkan dan telah memarasit $P$. xylostella selama pemeliharaan. Hal ini dilakukan karena perilaku parasitoid dalam memarasit umumnya terpengaruh oleh pengalaman sebelumnya (van Alphen \& Vet 1990) dan dapat juga dipengaruhi oleh genetik serta kondisi inang (Rehman \& Powell 2010). Parasitoid tadi dibiarkan berada di dalam kurungan selama kurang lebih 24 jam dan kemudian dipisahkan dari serangga inang perlakuan. Larva inang kemudian dipelihara sebelum dibedah.

Pengaruh ekstrak biji srikaya dalam tubuh inang $P$. xylostella terhadap perkembangan parasitoid $D$. semiclausum diamati dengan membedah satu individu larva inang per ulangan setiap hari. Pengamatan dilakukan terhadap tingkat parasitisasi imago D. semiclausum, kematian harian larva $P$. xylostella yang diparasit, perkembangan stadium pradewasa parasitoid dalam tubuh inang, dan waktu yang diperlukan parasitoid untuk menjadi imago. Dari pradewasa parasitoid yang berhasil ditemukan dalam pembedahan, 
dipilih enam ulangan setiap hari untuk mengukur perkembangan parasitoid secara kuantitatif. Peubah perkembangan parasitoid dalam tubuh inang yang digunakan adalah panjang tubuh, lebar tubuh, dan lebar kapsul kepala pradewasa $D$. semiclausum.

\section{Analisis data}

Analisis terhadap respons kematian harian $P$. xylostella dan imago $D$. semiclausum dilakukan dengan metode Probit (Finney 1971). Data perkembangan serangga diolah dengan analisis ragam dan uji lanjut dilakukan dengan metode Tukey (Steel \& Torrie 1993). Analisis ragam, uji Tukey, dan regresi linier dilakukan dengan memanfaatkan program komputer MSUSTAT (Lund 1986).

\section{HASIL}

\section{Toksisitas ekstrak biji srikaya terhadap larva P. xylostella}

Perlakuan ekstrak biji srikaya pada setiap konsentrasi uji dengan metode residu pada daun menyebabkan kematian larva $P$. xylostella. Semakin tinggi konsentrasi ekstrak biji srikaya yang digunakan, semakin besar persentase kematian larva $P$. xylostella. Hal ini konsisten hingga konsentrasi tertinggi yang digunakan $(0,2 \%$, kontaminasi 6 jam) (Gambar 1). Secara umum, kematian terbesar terjadi di antara hari pertama dan kedua. Setelah itu, pengaruh ekstrak biji srikaya berangsur-angsur turun dan tidak berpengaruh terhadap kematian larva $P$. xylostella. Apabila hasil ini dihubungkan dengan perkembangan larva $P$. xylostella (Tabel 2), kematian tertinggi bersamaan dengan saat ganti kulit atau beberapa saat sesudahnya.

Pada saat awal perlakuan, respons kematian larva P. xylostella umumnya rendah (kurang dari $50 \%$ ) kecuali pada perlakuan lama kontaminasi 6 jam. Perlakukan tersebut menyebabkan larva P. xylostella mati lebih cepat daripada perlakuanperlakuan lainnya karena konsentrasi yang digunakan lebih tinggi. Residu ekstrak biji srikaya pada awal perlakuan kontaminasi 6 jam telah mencapai dosis toksik bagi larva uji.

Dalam setiap perlakuan lama kontaminasi ekstrak biji srikaya, $\mathrm{LC}_{50}$ yang dihitung pada hari ke-2 dan hari-hari selanjutnya tidak menunjukkan perbedaan yang nyata (Tabel 1). Hal ini dapat dijelaskan dengan memperhatikan Gambar 1, yaitu sejak hari ke-2 dan seterusnya kurva relatif datar sehingga tidak terdapat perbedaan kematian larva yang nyata.

Hasil penghitungan $\mathrm{LC}_{50}$ untuk hari ke-2 dan seterusnya pada perlakuan lama kontaminasi 9 jam tidak ditampilkan mengingat korelasi liniemya tidak nyata. $\mathrm{LC}_{50}$ pada saat pertama pengamatan selalu jauh lebih besar daripada $\mathrm{LC}_{50}$ yang dihitung pada waktu-waktu selanjutnya (berlurut-turut $0,133 \%, 0,096 \%, 0,072 \%$, dan $0,064 \%$ pada 6,9 , 12, dan 24 jam setelah perlakuan). Berdasarkan pola perkembangan kematian larva dalam masingmasing konsentrasi uji, ekstrak biji srikaya belum menunjukkan sifat insektisida pada saat-saat awal (Gambar 1).

Gradien untuk berbagai waktu pengamatan pada masing-masing perlakuan lama kontaminasi tidak berbeda nyata dari hari ke hari kecuali pada perlakuan kontaminasi 12 jam yang diduga akibat keheterogenan data, seperti ditunjukkan oleh nilai $\mathrm{g}$, yang relatif besar $(>0,1)$. Dengan demikian, pengaruh ekstrak biji srikaya antar konsentrasi pada setiap perlakuan lama kontaminasi secara umum menunjukkan pola yang konsisten. Artinya, pada setiap saat pencatatan data kematian, perlakuan dengan konsentrasi rendah selalu menyebabkan proporsi kematian yang lebih rendah daripada proporsi kematian akibat konsentrasi yang lebih tinggi dalam setiap taraf lama kontaminasi ekstrak.

\section{Hambatan perkembangan $P$.xylostella pradewasa}

Perlakuan dengan ekstrak biji srikaya cenderung menghambat perkembangan larva $P$. xylostella yang bertahan hidup (Tabel 2). Namun, hanya beberapa konsentrasi perlakuan yang mengakibatkan pengaruh yang nyata (konsentrasi $0,04 \%, 0,0632 \%, 0,1 \%$ pada perlakuan kontaminasi 24 jam, konsentrasi $0,015 \%$ pada perlakuan kontaminasi 12 jam serta konsentrasi $0,032 \%$ dan 0,08\% pada perlakuan kontaminasi 6 jam).

Lama perkembangan larva instar III $P$. xylostella dan pembentukan pupa cenderung bertambah panjang dengan semakin tinggi konsentrasi yang digunakan pada setiap perlakuan lama kontaminasi (Tabel 2). Setiap nilai rata-rata \pm simpangan baku bertumpang tindih yang berarti tidak ada perbedaan nyata. Dengan demikian, pengaruh kontaminasi ekstrak biji srikaya terhadap 

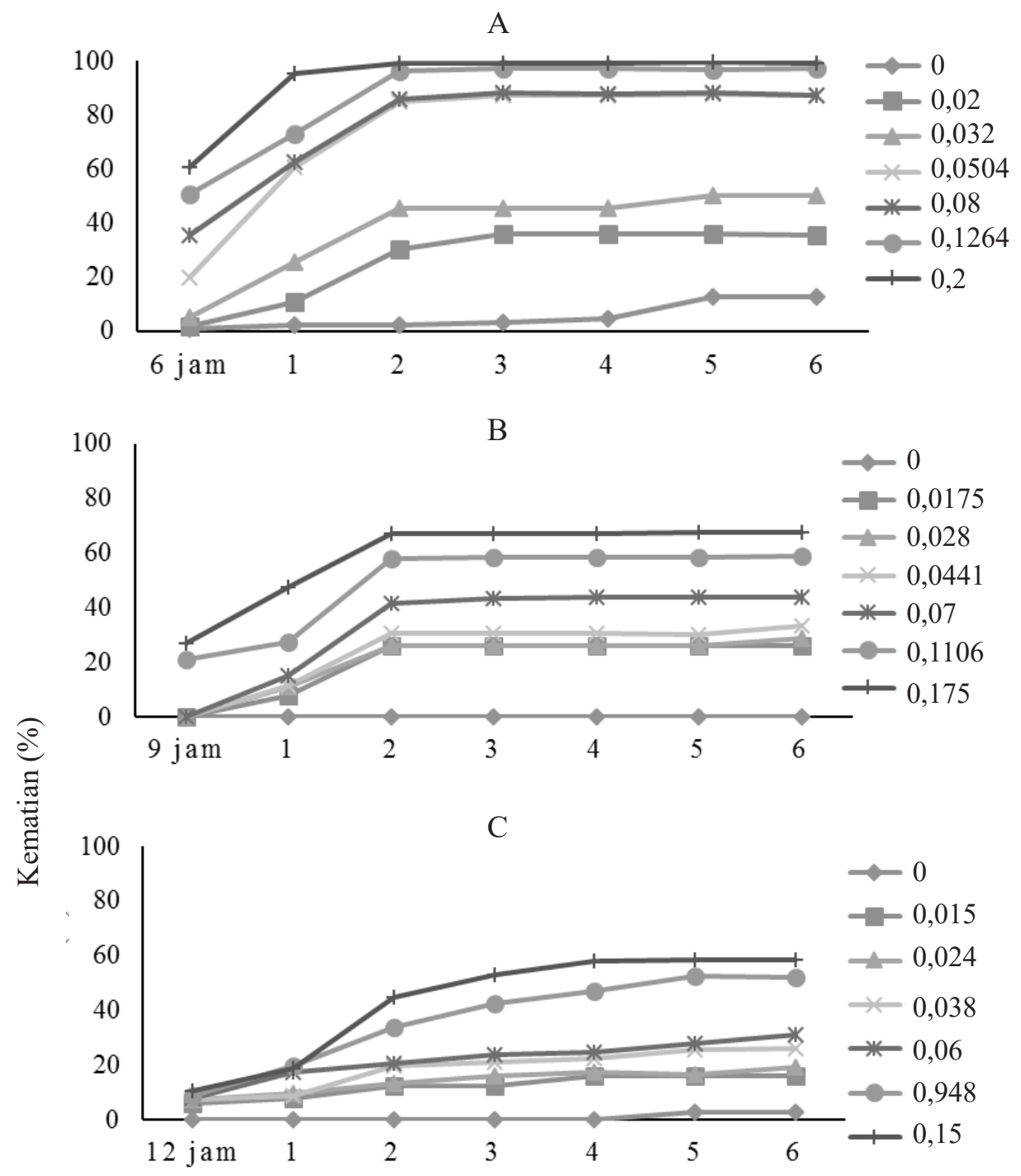

$\mathrm{D}$

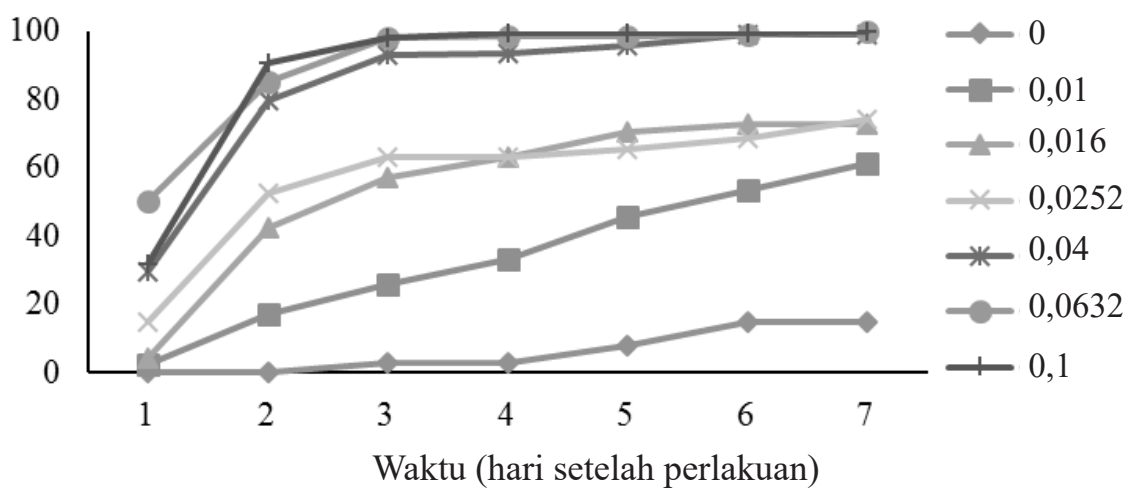

Gambar 1. Perkembangan kematian larva Plutella xylostella yang diberi perlakuan ekstrak biji srikaya dengan lama pemberian pakan/kontaminasi A: 6 jam; B: 9 jam; C: 12 jam; dan D: 24 jam.

lama perkembangan larva P. xylostella pradewasa relatif kecil. Pengaruh ekstrak biji srikaya pada konsentrasi rendah terhadap lama perkembangan P. xylostella pradewasa mungkin dapat diabaikan.

Berdasarkan persentase keberhasilan larva $P$. xylostella menjadi larva instar IV, pupa, dan Imago, ternyata pengaruh merugikan ekstrak biji srikaya hanya terlihat nyata pada persentase keberhasilan larva instar III menjadi instar IV (Tabel 3). Setelah P. xylostella berhasil menjadi larva instar IV, hanya sedikit perbedaan persentase pupa yang terbentuk antar taraf konsentrasi. Pengaruh ekstrak biji 
Tabel 1. Parameter toksisitas ekstrak biji srikaya berdasarkan analisis probit data kematian Plutella xylostella

\begin{tabular}{|c|c|c|c|c|c|}
\hline $\begin{array}{l}\text { Lama } \\
\text { kontaminasi (jam) }\end{array}$ & $\begin{array}{l}\text { Waktu } \\
\text { analisis }\end{array}$ & Gradien $\pm s b$ & $\begin{array}{c}\mathrm{LC}_{50} \\
(\% \mathrm{w} / \mathrm{v})\end{array}$ & $\begin{array}{c}\text { Selang kepercayaan } 95 \% \\
\text { untuk } \mathrm{LC}_{50}(\% \mathrm{w} / \mathrm{v})\end{array}$ & $\begin{array}{c}\text { g (keheterogenan } \\
\text { data) }\end{array}$ \\
\hline \multirow[t]{8}{*}{$\overline{6}$} & 6 jam & $2,395 \pm 0,330$ & 0,133 & $0,110-0,173$ & 0,073 \\
\hline & 1 hari & $2,708 \pm 0,336$ & 0,064 & $0,053-0,077$ & 0,059 \\
\hline & 2 hari & $2,925 \pm 0,384$ & 0,034 & $0,027-0,041$ & 0,066 \\
\hline & 3 hari & $3,009 \pm 0,397$ & 0,032 & $0,025-0,038$ & 0,067 \\
\hline & 4 hari & $3,009 \pm 0,397$ & 0,032 & $0,025-0,038$ & 0,067 \\
\hline & 5 hari & $3,009 \pm 0,397$ & 0,032 & $0,025-0,038$ & 0,067 \\
\hline & 6 hari & $3,009 \pm 0,397$ & 0,032 & $0,025-0,038$ & 0,067 \\
\hline & 7 hari & $3,009 \pm 0,397$ & 0,032 & $0,025-0,038$ & 0,067 \\
\hline \multirow[t]{2}{*}{9} & 9 jam & $2,625 \pm 0,370$ & 0,096 & $0,080-0,118$ & 0,076 \\
\hline & 1 hari & $2,054 \pm 0,565$ & 0,033 & $0,001-0,071$ & 0,765 \\
\hline \multirow[t]{4}{*}{12} & 12 jam & $1,924 \pm 0,280$ & 0,072 & $0,059-0,094$ & 0,081 \\
\hline & 1 hari & $2,013 \pm 0,508$ & 0,031 & $0,008-0,064$ & 0,645 \\
\hline & 2 hari & $0,690 \pm 0,503$ & 0,015 & $0,010-0,019$ & 0,135 \\
\hline & 3 hari & $3,461 \pm 0,722$ & 0,014 & $0,010-0,018$ & 0,167 \\
\hline \multirow[t]{5}{*}{24} & 24 jam & $2,587 \pm 0,465$ & 0,064 & $0,050-0,096$ & 0,124 \\
\hline & 2 hari & $2,268 \pm 0,292$ & 0,022 & $0,018-0,026$ & 0,064 \\
\hline & 3 hari & $2,982 \pm 0,386$ & 0,016 & $0,013-0,019$ & 0,064 \\
\hline & 4 hari & $3,108 \pm 0,424$ & 0,016 & $0,012-0,020$ & 0,072 \\
\hline & 5 hari & $2,804 \pm 0,428$ & 0,014 & $0,010-0,018$ & 0,090 \\
\hline
\end{tabular}

Tabel 2. Lama perkembangan larva Plutella xylostella yang diberi perlakuan ekstrak biji srikaya sejak larva instar III hingga terbentuk pupa

\begin{tabular}{|c|c|c|c|c|c|}
\hline \multirow{3}{*}{$\begin{array}{l}\text { Lama } \\
\text { kontaminasi (jam) } \\
6\end{array}$} & \multirow{3}{*}{$\begin{array}{l}\text { Konsentrasi } \\
(\% \mathrm{w} / \mathrm{v})\end{array}$} & \multicolumn{4}{|c|}{ Lama perkembangan $(\mathrm{x} \pm \mathrm{sb}), \mathrm{n}$ (hari) } \\
\hline & & \multicolumn{2}{|c|}{ Instar III-instar IV } & \multicolumn{2}{|c|}{ Instar III-pupa } \\
\hline & & $1,000 \pm 0,000$ & 39 & $3,774 \pm 0,845$ & 31 \\
\hline & 0,02 & $1,000 \pm 0,000$ & 30 & $4,333 \pm 0,702$ & 24 \\
\hline & 0,032 & $1,043 \pm 0,209$ & 23 & $5,125 \pm 0,500$ & 16 \\
\hline & 0,0504 & $1,000 \pm 0,000$ & 10 & $4,800 \pm 0,447$ & 5 \\
\hline & 0,08 & $1,000 \pm 0,000$ & 8 & $5,000 \pm 0,000$ & 4 \\
\hline & 0,1264 & $1,000 \pm 0,000$ & 5 & & \\
\hline & 0,2 & - & & & \\
\hline \multirow[t]{7}{*}{9} & 0 & $1,000 \pm 0,000$ & 39 & $3,162+0,764$ & 37 \\
\hline & 0,0175 & $1,077 \pm 0,272$ & 26 & $3,809 \pm 0,750$ & 24 \\
\hline & 0,028 & $1,100 \pm 0,305$ & 30 & $3,926 \pm 0,385$ & 27 \\
\hline & 0,0441 & $1,130 \pm 0,344$ & 23 & $4,292 \pm 0,751$ & 22 \\
\hline & 0,07 & $1,292 \pm 0,464$ & 24 & $4,150 \pm 0,745$ & 21 \\
\hline & 0,1106 & $1,158 \pm 0,375$ & 19 & $4,188 \pm 1,109$ & 16 \\
\hline & 0,175 & $1,333 \pm 0,651$ & 12 & $4,091 \pm 0,944$ & 11 \\
\hline \multirow[t]{7}{*}{12} & 0 & $1,025 \pm 0,158$ & 40 & $3,256 \pm 0,442$ & 39 \\
\hline & 0,015 & $1,021 \pm 0,410$ & 34 & $4,030 \pm 0,529$ & 33 \\
\hline & 0,024 & $1,355 \pm 0,608$ & 31 & $4,143 \pm 0,591$ & 28 \\
\hline & 0,038 & $1,444 \pm 0,506$ & 27 & $4,042 \pm 0,204$ & 24 \\
\hline & 0,06 & $1,581 \pm 0,564$ & 30 & $4,346 \pm 0,689$ & 26 \\
\hline & 0,0948 & $1,500 \pm 0,511$ & 23 & $4,556 \pm 1,149$ & 19 \\
\hline & 0,015 & $1,550 \pm 0,510$ & 20 & $4,385 \pm 0,650$ & 13 \\
\hline \multirow[t]{7}{*}{24} & 0 & $1,052 \pm 0,226$ & 38 & $4,059 \pm 0,886$ & 34 \\
\hline & 0,01 & $1,194 \pm 0,477$ & 31 & $4,235 \pm 0,903$ & 17 \\
\hline & 0,016 & $1,526 \pm 0,513$ & 19 & $5,000 \pm 0,816$ & 10 \\
\hline & 0,0252 & $1,733 \pm 0,458$ & 15 & $5,125 \pm 0,354$ & 8 \\
\hline & 0,04 & $2,000 \pm 0,000$ & 3 & $5,000 \pm-$ & 1 \\
\hline & 0,0632 & $2,000 \pm 0,000$ & 2 & & \\
\hline & 0,1 & $3,000 \pm-$ & 1 & & \\
\hline
\end{tabular}


srikaya terhadap banyaknya imago yang muncul dari pupa yang berhasil terbentuk tidak berbeda nyata (Tabel 3). Setelah larva P. xylostella berhasil melewati masa instar IV, pengaruh ekstrak biji srikaya pada perkembangan serangga menurun.

\section{Pengaruh kontak ekstrak biji srikaya terhadap} imago D. semiclausum

Tingkat kematian imago D. semiclausum relatif tidak berubah setiap harinya. Ekstrak biji srikaya dengan taraf konsentrasi tinggi langsung menyebabkan kematian yang tinggi sehari setelah perlakuan. Pada hari-hari selanjutnya, tidak terjadi penambahan kematian yang berarti. Sementara itu, perlakuan dengan taraf konsentrasi rendah $(0,01 \%$ dan 0,016\%) hanya menyebabkan kematian yang rendah pada saat awal. Namun, pada harihari berikutnya kematian imago $D$. semiclausum meningkat dengan peningkatan cukup tinggi sehingga kemiringan kurva kematian lebih tajam. Ekstrak biji srikaya dengan konsentrasi tinggi $(0,1 \%, 0,0632 \%)$ memiliki pengaruh yang cepat terhadap kematian imago D. semiclausum, sedangkan ekstrak biji srikaya dengan konsentrasi

Tabel 3. Persentase keberhasilan larva Plutella xylostella yang diberi perlakuan ekstrak biji srikaya menjadi larva instar IV, pupa, dan imago

\begin{tabular}{|c|c|c|c|c|}
\hline $\begin{array}{l}\text { Lama } \\
\text { kontaminasi (jam) }\end{array}$ & $\begin{array}{l}\text { Konsentrasi } \\
(\% \mathrm{w} / \mathrm{v})\end{array}$ & $\begin{array}{l}\text { Keberhasilan menjadi } \\
\text { larva instar } \mathrm{IV}^{1}(\%)\end{array}$ & $\begin{array}{c}\text { Keberhasilan } \\
\text { menjadi pupa }^{2}(\%)\end{array}$ & $\begin{array}{c}\text { Keberhasilan menjadi } \\
\text { imago }^{3)}(\%)\end{array}$ \\
\hline 6 & $\begin{array}{c}0 \\
0,02 \\
0,032 \\
0,0504 \\
0,08 \\
0,1264 \\
0,2\end{array}$ & $\begin{array}{l}97,5 \mathrm{~d} \\
75,0 \mathrm{dc} \\
57,5 \mathrm{bc} \\
25 \mathrm{ab} \\
12,5 \mathrm{a} \\
0,0 \mathrm{a}\end{array}$ & $\begin{array}{c}79,8 \mathrm{~b} \\
80,0 \mathrm{~b} \\
64,8 \mathrm{ab} \\
45,8 \mathrm{a} \\
27,0 \mathrm{ab} \\
2,5 \mathrm{a}\end{array}$ & \\
\hline 9 & $\begin{array}{c}0 \\
0,0175 \\
0,028 \\
0,0441 \\
0,07 \\
0,1106 \\
0,175\end{array}$ & $\begin{array}{l}97,5 \mathrm{c} \\
65,0 \mathrm{abc} \\
75,0 \mathrm{bc} \\
57,5 \mathrm{ab} \\
60,0 \mathrm{ab} \\
47,5 \mathrm{ab} \\
30,0 \mathrm{a}\end{array}$ & $\begin{array}{l}95,0 \mathrm{a} \\
94,0 \mathrm{a} \\
89,8 \mathrm{a} \\
91,5 \mathrm{a} \\
86,3 \mathrm{a} \\
86,8 \mathrm{a} \\
95,0 \mathrm{a}\end{array}$ & $\begin{array}{r}92,0 \mathrm{a} \\
89,3 \mathrm{a} \\
91,5 \mathrm{a} \\
91,8 \mathrm{a} \\
100,0 \mathrm{a} \\
93,8 \mathrm{a} \\
93,8 \mathrm{a}\end{array}$ \\
\hline 12 & $\begin{array}{c}0 \\
0,015 \\
0,024 \\
0,038 \\
0,06 \\
0,0948 \\
0,015\end{array}$ & $\begin{array}{l}100,0 \mathrm{~b} \\
82,5 \mathrm{ab} \\
77,5 \mathrm{ab} \\
67,5 \mathrm{ab} \\
77,5 \mathrm{ab} \\
57,5 \mathrm{a} \\
50,0 \mathrm{a}\end{array}$ & $\begin{array}{r}97,5 \mathrm{a} \\
100,0 \mathrm{a} \\
90,8 \mathrm{a} \\
91,3 \mathrm{a} \\
83,0 \mathrm{a} \\
75,0 \mathrm{a} \\
62,3 \mathrm{a}\end{array}$ & $\begin{array}{l}79,0 \mathrm{a} \\
94.0 \mathrm{a} \\
88,3 \mathrm{a} \\
82,8 \mathrm{a} \\
79,3 \mathrm{a} \\
76,3 \mathrm{a} \\
75,0 \mathrm{a}\end{array}$ \\
\hline 24 & $\begin{array}{c}0 \\
0,01 \\
0,016 \\
0,0252 \\
0,04 \\
0,0632 \\
0,1\end{array}$ & $\begin{array}{r}95,0 \mathrm{c} \\
77,5 \mathrm{c} \\
47,5 \mathrm{~b} \\
37,5 \mathrm{~b} \\
7,5 \mathrm{a} \\
5,0 \mathrm{a} \\
2,5 \mathrm{a}\end{array}$ & $\begin{array}{l}89,5 \mathrm{~b} \\
50,5 \mathrm{ab} \\
52,5 \mathrm{ab} \\
41,75 \mathrm{a}\end{array}$ & $\begin{array}{l}70,0 \mathrm{a} \\
55,8 \mathrm{a} \\
47,5 \mathrm{a} \\
66,8 \mathrm{a}\end{array}$ \\
\hline
\end{tabular}

Angka dalam kolom yang sama dan diikuti huruf yang sama tidak berbeda nyata menurut uji statistik Tukey pada taraf nyata 5\%. Beberapa data persentase keberhasilan menjadi pupa dan imago tidak ditampilkan karena data jumlah P. xylostella terlalu sedikit untuk diolah.

${ }^{1)}$ dihitung berdasarkan jumlah larva instar III saat awal perlakuan;

${ }^{2)}$ dihitung berdasarkan jumlah larva yang berhasil menjadi instar IV;

${ }^{3)}$ dihitung berdasarkan jumlah larva instar IV yang berhasil menjadi pupa; 
rendah $(0,01 \%, 0,016 \%)$ memiliki pengaruh yang lebih lambat, tetapi tetap berpotensi merugikan (Gambar 2).

Bila dibandingkan dengan pengaruhnya terhadap larva P. xylostella (Tabel 1), $\mathrm{LC}_{50}$ terhadap D. semiclausum tidak berbeda atau sedikit lebih tinggi dibandingkan $P$. xylostella (Tabel 4 dan Tabel 1). Ekstrak biji srikaya sedikit lebih toksik terhadap $P$. xylostella dibandingkan terhadap $D$. semiclausum. Pengecualian terjadi pada pengamatan hari pertama yang menunjukkan $\mathrm{LC}_{50}$ terhadap imago D. semiclausum $(0,027 \%)$ lebih rendah daripada $\mathrm{LC}_{50}$ terhadap larva $P$. xylostelta $(0,064 \%)$.

Namun demikian, gradien pada $D$. semiclausum lebih tinggi (kurva lebih tegak). Hal ini berarti peningkatan respons kematian $D$. semiclausum lebih besar dengan peningkatan konsentrasi yang sama.

Pengaruh residu ekstrak biji srikaya dalam tubuh inang terhadap tingkat parasitisasi oleh D. semiclausum

Perlakuan dengan konsentrasi subletal $\left(\mathrm{LC}_{5}\right.$ dan $\mathrm{LC}_{10}$ ) terhadap inang tidak mempengaruhi persentase parasitisasi oleh $D$. semiclausum (Tabel 5).

Tingkat parasitisasi selama 24 jam pada perlakuan lama kontaminasi 24 jam lebih tinggi daripada 12 jam dan 6 jam walaupun tidak ber- beda nyata (Tabel 5). Rata-rata jumlah telur yang diletakkan oleh satu individu $D$. semiclausum pada perlakuan kontaminasi 24 jam sedikit lebih tinggi dibandingkan pada perlakuan 12 dan 6 jam, sedangkan antar taraf konsentrasi dalam masing-masing waktu kontaminasi tidak terdapat perbedaan nyata. Namun demikian, data ini mungkin menunjukkan nilai yang lebih kecil daripada nilai sebenarnya karena banyak larva inang mati yang telah membusuk saat dilakukan pembedahan sehingga tidak diketahui apakah inang tersebut terparasit atau tidak.

\section{Pengaruh residu ekstrak biji srikaya terhadap perkembangan $D$. semiclausun pradewasa}

Pengaruh terhadap bobot, panjang dan lebar kokon D. semiclausum. Bobot, panjang dan lebar kokon $D$. semiclausum tidak terpengaruh oleh keberadaan ekstrak biji srikaya. Ratarata bobot kokon dalam inang yang mendapat perlakuan ekstrak biji srikaya berkisar antara 3,6-4,3 mg, tidak berbeda nyata dengan kontrol, yaitu 3,9-4,2 mg. Kokon yang dihasilkan tampak normal dan pupa yang berkembang di dalamnya tidak menunjukkan kelainan (Tabel 6).

Pengaruh terhadap lama perkembangan D. semiclausum menjadi imago. Kecuali pada perlakuan $\mathrm{LC}_{10}$ dengan lama kontaminasi 24 jam,

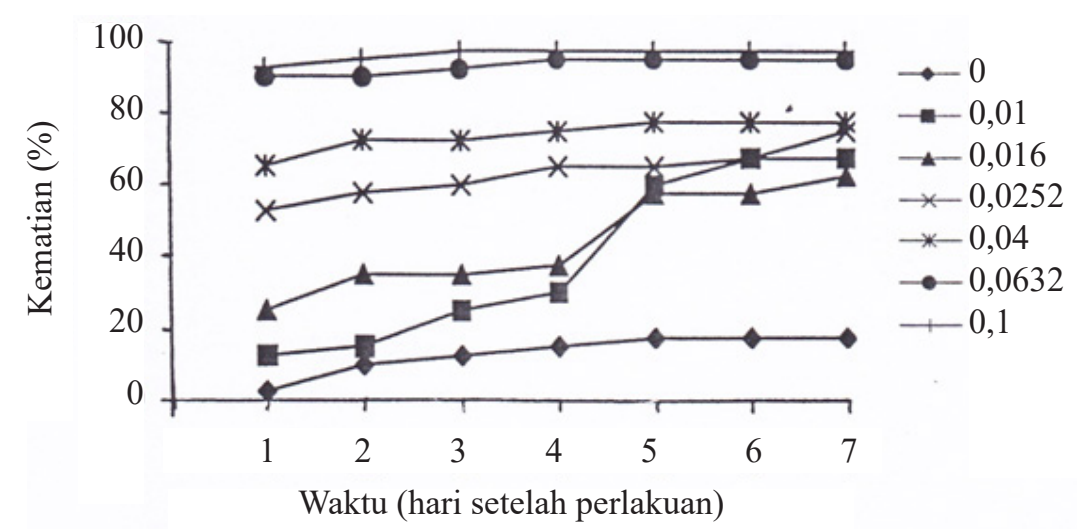

Gambar 2. Perkembangan kematian imago Diadegma semiclausum akibat pengaruh kontak residu ekstrak biji srikaya.

Tabel 4. Parameter toksisitas kontak ekstrak biji srikaya terhadap Diadegma semiclausum

\begin{tabular}{lccc}
\hline $\begin{array}{l}\text { Saat pengamatan } \\
\text { (hari) }\end{array}$ & Gradien $+\mathrm{sb}$ & $\begin{array}{c}\mathrm{LC}_{50}(\text { selang kepercayaan 95\%) } \\
(\% \mathrm{w} / \mathrm{v})\end{array}$ & $\begin{array}{c}\text { g (keheterogenan } \\
\text { data) }\end{array}$ \\
\hline 1 & $2,900 \pm 0,338$ & $0,027(0,023-0,031)$ & 0,052 \\
2 & $3,006 \pm 0,393$ & $0,026(0,022-0,031)$ & 0,066 \\
3 & $3,042 \pm 0,408$ & $0,025(0,020-0,029)$ & 0,070 \\
4 & $3,025 \pm 0,418$ & $0,023(0,019-0,028)$ & 0,073 \\
\hline
\end{tabular}


tidak ada perbedaan nyata antar perlakuan dalam hal lama waktu yang diperlukan D. semiclausum jantan maupun betina untuk menjadi imago (Tabel 7). Imago jantan membutuhkan waktu 11,3-13,5 hari, sedangkan imago betina membutuhkan waktu 11,5-13,4 hari. Dengan demikian, keberadaan ekstrak biji srikaya dalam konsentrasi subletal tidak menghambat perkembangan $D$. semiclausum menjadi imago. Walaupun demikian, imago jantan maupun betina parasitoid yang dihasilkan berukuran lebih kecil dan tampak lebih lemah dibandingkan dengan imago yang diperoleh dari lapang. Hal ini mungkin disebabkan teknik pemeliharaan di laboratorium yang berbeda dengan kondisi di lapang.

Tabel 5. Tingkat parasitisasi, superparasitisasi, dan perkiraan jumlah telur minimal Diadegma semiclausum selama 24 jam pada Plutella xylostella yang diberi perlakuan konsentrasi subletal ekstrak biji srikaya

\begin{tabular}{|c|c|c|c|c|}
\hline \multicolumn{2}{|c|}{ Perlakuan } & \multirow{2}{*}{$\frac{\text { Parasitisasi (\%) }}{68,2 \mathrm{a}}$} & \multirow{2}{*}{$\frac{\text { Superparasitisasi }(\%)}{5,8 \mathrm{a}}$} & \multirow{2}{*}{$\begin{array}{c}\begin{array}{c}\text { Rata-rata jumlah } \\
\text { telur yang diletakkan }\end{array} \\
8,0 \pm 4,2\end{array}$} \\
\hline $6 \mathrm{jam}$ & Kontrol & & & \\
\hline & $\mathrm{LC}_{5}$ & $63,5 \mathrm{a}$ & $0,8 \mathrm{a}$ & $5,9 \pm 2,8$ \\
\hline & $\mathrm{LC}_{10}$ & $64,4 \mathrm{a}$ & $4,3 \mathrm{a}$ & $6,1 \pm 3,7$ \\
\hline \multirow[t]{3}{*}{$12 \mathrm{jam}$} & Kontrol & $76,1 \mathrm{a}$ & $1,7 \mathrm{a}$ & $7,3 \pm 4,3$ \\
\hline & $\mathrm{LC}_{5}$ & $96,7 \mathrm{a}$ & $3,6 \mathrm{a}$ & $4,7 \pm 3,1$ \\
\hline & $\mathrm{LC}_{10}^{3}$ & $94,8 \mathrm{a}$ & $1,8 \mathrm{a}$ & $6,2 \pm 3,9$ \\
\hline \multirow[t]{3}{*}{$24 \mathrm{jam}$} & Kontrol & 59,9 a & $9,6 \mathrm{a}$ & $11,5 \pm 4,3$ \\
\hline & $\mathrm{LC}_{5}$ & $49,1 \mathrm{a}$ & $13,5 \mathrm{a}$ & $12,6 \pm 2,7$ \\
\hline & $\mathrm{LC}_{10}$ & $63,9 \mathrm{a}$ & $9,1 \mathrm{a}$ & $12,5 \pm 4,8$ \\
\hline
\end{tabular}

Angka dalam kolom yang sama dan diikuti huruf yang sama tidak berbeda nyata menurut uji statistik Tukey pada taraf nyata $5 \%$.

Tabel 6. Bobot, panjang, dan lebar kokon Diadegma semiclausum yang dipelihara dalam inang Plutella xylostella yang diberi perlakuan konsentrasi subletal ekstrak biji srikaya

\begin{tabular}{|c|c|c|c|c|}
\hline \multicolumn{2}{|c|}{ Perlakuan } & \multirow{2}{*}{$\frac{\text { Bobot }^{1)}(\mathrm{mg})}{4,0 \mathrm{a}}$} & \multirow{2}{*}{$\begin{array}{c}\text { Panjang }^{1)}(\mathrm{mm}) \\
4,73 \mathrm{a}\end{array}$} & \multirow{2}{*}{$\begin{array}{c}\text { Lebar }^{1)}(\mathrm{mm}) \\
1,59 \mathrm{a}\end{array}$} \\
\hline 24 jam & Kontrol & & & \\
\hline & $\mathrm{LC}_{5}$ & $4,2 \mathrm{a}$ & $4,76 \mathrm{a}$ & $1,61 \mathrm{a}$ \\
\hline & $\mathrm{LC}_{10}$ & $4,3 \mathrm{a}$ & $4,67 \mathrm{a}$ & $1,57 \mathrm{a}$ \\
\hline \multirow[t]{3}{*}{$12 \mathrm{jam}$} & Kontrol & $3,9 \mathrm{a}$ & $4,44 \mathrm{a}$ & $1,52 \mathrm{a}$ \\
\hline & $\mathrm{LC}_{5}$ & $3,8 \mathrm{a}$ & $4,41 \mathrm{a}$ & $1,52 \mathrm{a}$ \\
\hline & $\mathrm{LC}_{10}$ & $3,6 \mathrm{a}$ & $4,39 \mathrm{a}$ & $1,50 \mathrm{a}$ \\
\hline \multirow[t]{3}{*}{6 jam } & Kontrol & $4,2 \mathrm{a}$ & $4,51 \mathrm{a}$ & $1,44 \mathrm{a}$ \\
\hline & $\mathrm{LC}_{5}$ & $4,2 \mathrm{a}$ & $4,47 \mathrm{a}$ & $1,43 \mathrm{a}$ \\
\hline & $\mathrm{LC}_{10}$ & $4,0 \mathrm{a}$ & $4,41 \mathrm{a}$ & $1,42 \mathrm{a}$ \\
\hline
\end{tabular}

1) tidak ada perbedaan respons yang nyata antar perlakuan menurut uji Tukey pada taraf nyata 5\%.

Tabel 7. Waktu yang diperlukan Diadegma semiclausum untuk menjadi imago dalam inang yang diberi perlakuan konsentrasi subletal ekstrak biji srikaya

\begin{tabular}{|c|c|c|c|c|c|}
\hline \multirow{2}{*}{\multicolumn{2}{|c|}{ Perlakuan }} & \multicolumn{4}{|c|}{ Lama perkembangan menjadi imago (hari), (n) } \\
\hline & & \multicolumn{2}{|c|}{ Jantan } & \multicolumn{2}{|c|}{ Betina } \\
\hline \multirow[t]{3}{*}{$6 \mathrm{jam}$} & Kontrol & $11,3 \pm 0,6$ & (3) & $12,0 \pm-$ & (3) \\
\hline & $\mathrm{LC}_{5}$ & $12,0 \pm-$ & (1) & $11,5 \pm 0,7$ & (2) \\
\hline & $\mathrm{LC}_{10}$ & $12,7 \pm 0,6$ & (3) & - & $(0)$ \\
\hline \multirow[t]{3}{*}{12 jam } & Kontrol & $13,5 \pm 0,7$ & $(15)$ & $13,2 \pm 0,8$ & $(10)$ \\
\hline & $\mathrm{LC}_{5}$ & $12,7 \pm 0,5$ & $(7)$ & $13,0 \pm 1,0$ & (3) \\
\hline & $\mathrm{LC}_{10}$ & $13,3 \pm 0,8$ & (17) & $13,4 \pm 0,7$ & $(17)$ \\
\hline \multirow[t]{3}{*}{24 jam } & Kontrol & $13,3 \pm 1,6$ & (3) & $12,0 \pm-$ & (3) \\
\hline & $\mathrm{LC}_{5}$ & $13,5 \pm 0,6$ & (4) & $11,5 \pm 0,6$ & (2) \\
\hline & $\mathrm{LC}_{10}$ & $13,0 \pm 0,6$ & (6) & $13,0 \pm-$ & (1) \\
\hline
\end{tabular}




\section{PEMBAHASAN}

Ekstrak biji srikaya pada konsentrasi $0,04 \%$, $0,0632 \%$, dan $0,1 \%$ dengan kontaminasi selama 24 jam serta konsentrasi $0,08 \%, 0,1264 \%$, dan $0,2 \%$ dengan kontaminasi selama 6 jam efektif menyebabkan kematian larva $P$. xylostella lebih dari $80 \%$ pada 2 hari setelah perlakuan. Sementara itu, dengan waktu kontaminasi 24 jam, konsentrasi $0,0632 \%$ dan $0,1 \%$ ekstrak biji srikaya menyebabkan kematian lebih dari $80 \%$ imago $D$. semiclausum karena pengaruh kontak.. Pengaruh kontak ekstrak biji srikaya terhadap imago $D$. semiclausum telah terlihat sejak hari pertama dan mempunyai kemiringan kurva regresi probit yang lebih tajam. Hal ini menunjukkan kematian imago D. semiclausum akibat kontak dengan ekstrak biji srikaya lebih responsif terhadap peningkatan konsentrasi ekstrak. Kepekaan parasitoid terhadap insektisida juga dilaporkan oleh Idris \& Grafius (1993a), yaitu $D$. insulare lebih peka terhadap permetrin dan azinfosmetil dibandingkan dengan inangnya. Permetin dan azinfosmetil dapat menyebabkan kematian $D$. insulare hingga $100 \%$, sementara inangnya tidak terpengaruh sama sekali (Idris \& Grafius 1993a). Kepekaan respons tersebut diduga karena imago D. semiclausum lebih aktif bergerak selama perlakuan sehingga kontak dengan permukaan yang mengandung ekstrak biji srikaya lebih sering. Secara umum, Waage (1992) mengemukakan bahwa salah satu penyebab kerentanan musuh alami termasuk parasitoid terhadap insektisida adalah aktivitasnya yang lebih tinggi dibandingkan dengan serangga inang.

Kontaminasi yang lebih lama (24 jam) menyebabkan kematian larva $P$. xylostella yang sama besarnya bila dibandingkan dengan perlakuan dengan konsentrasi dua kali lebih tinggi, tetapi waktu kontaminasinya lebih singkat (6 jam). Konsentrasi 0,04\% dengan kontaminasi selama 24 jam ternyata efektif mematikan larva $P$. xylostella tanpa berakibat kematian $D$. semiclausum yang lebih besar. Dalam kaitannya dengan peluang penerapan di lapangan, ekstrak biji srikaya tampaknya lebih baik digunakan dalam konsentrasi rendah. Pertimbangannya, ekstrak pada konsentrasi rendah telah efektif mematikan P. xylostella dengan sedikit mengurangi risiko kematian parasitoid D. semiclausum. Kematian musuh alami akibat insektisida secara teoretis diketahui menyebabkan resurjensi hama yang berarti kerugian dalam pengendalian (van den Bosch et al. 1985; Dutcher 2007).

Penelitian di lapangan perlu dilakukan untuk mengetahui keefektifan ekstrak biji srikaya terhadap hama $P$. xylostella dan dampaknya terhadap D. semiclausum mengingat banyak faktor di lapangan yang mempengaruhi hasil pengendalian. Karena ekstrak biji srikaya mudah terurai (Prijono \& Triwidodo 1994), penggunaan di lapangan dalam konsentrasi rendah mungkin tidak efektif. Selain itu, pengaruh ekstrak biji srikaya terhadap parasitoid mungkin tidak sebesar yang diduga karena di lapangan terdapat tumbuhan suku Brassicaceae sebagai tempat berlindung bagi D. semiclausum pada saat aplikasi insektisida.

Pemaparan P. xylostella pada ekstrak biji srikaya dengan konsentrasi di bawah $\operatorname{LC}_{50}(0,02 \%$ dengan kontaminasi 6 jam, $0,0175 \%$ dengan kontaminasi 9 jam kontaminasi, $0,015 \%$ dengan kontaminasi 12 jam kontaminasi serta $0,1 \%$ dengan kontaminasi 24 jam kontaminasi) ternyata tidak berpengaruh nyata terhadap banyaknya individu yang berhasil ganti kulit, membentuk pupa, dan imago. Demikian pula, konsentrasi tersebut tidak memperpanjang waktu perkembangan $P$. xylostella pradewasa secara nyata. Pada sisi lain, perlakuan ekstrak biji srikaya pada $\mathrm{LC}_{5}$ dan $\mathrm{LC}_{10}$ terhadap inang P. xylostella tidak mempengaruhi persentase parasitisasi dan perkembangan $D$. semiclausum pradewasa bila dibandingkan dengan kontrol. Mungkin karena $P$. xylostella mampu mengeliminasi senyawa aktif ekstrak dalam tubuhnya atau karena $D$. semiclausum memiliki toleransi terhadap senyawa aktif ekstrak dalam tubuh inang, perlakuan dengan konsentrasi subletal tidak berpengaruh merugikan terhadap parasitoid. Diduga D. semiclausum memperoleh nutrisi dalam jumlah cukup dan berkualitas walaupun inangnya mengandung ekstrak biji srikaya dalam konsentrasi subletal. Walaupun ekstrak biji srikaya dapat menurunkan kualitas inang dan hal tersebut mungkin dikenali oleh $D$. semiclausum, belum berarti akan terjadi penurunan tingkat parasitisasi. Kualitas inang hanya salah satu faktor yang mempengaruhi keputusan parasitoid ketika bertemu inang, apakah akan memarasit inang yang 
ditemui tanpa melakukan seleksi kualitas apabila terdapat resiko kematian parasitoid saat memarasit (Strand 1988), atau inang melakukan perlawanan (Godfray 1994), atau peluang menemukan inang relatif kecil (Strand 1990). Berkaitan dengan aspek fisiologis serangga inang, penurunan kualitas inang justru mungkin menguntungkan parasitoid karena mekanisme pertahanan diri inang melemah (Godfray 1994).

Berdasarkan hal-hal yang telah diuraikan diatas dapat dikemukakan bahwa terdapat peluang memadukan pengendalian $P$. xylostella secara kimiawi menggunakan ekstrak biji srikaya dan pengendalian hayati yang memanfaatkan parasitoid D. semiclausum. Untuk mengukur besarnya peluang kesesuaian cara-cara pengendalian tersebut diperlukan penelitian lebih lanjut di lapangan.

\section{KESIMPULAN}

Ekstrak biji srikaya pada konsentrasi $0,0632-$ $0,1 \%$ dengan lama kontaminasi 24 jam berpengaruh terhadap kematian larva P. xylostella dan imago parasitoid $D$. semiclausum. Imago parasitoid lebih peka terhadap peningkatan konsentrasi ekstrak biji srikaya dibandingkan dengan larva $P$. xylostella. Hambatan perkembangan P. xylostella oleh ekstrak biji srikaya pada konsentrasi yang digunakan dalam perlakuan umumnya tidak nyata. Demikian pula, hambatan perkembangan parasitoid $D$. semiclausum dalam inang yang terkontaminasi konsentrasi subletal $\left(\mathrm{LC}_{5}\right.$ dan $\left.\mathrm{LC}_{10}\right)$ ekstrak biji srikaya tidak berbeda nyata. Keberadaan ekstrak biji srikaya dalam inang juga tidak berpengaruh nyata terhadap tingkat parasitisasi, panjang kokon, lebar kokon, dan bobot kokon D. semiclausum.

\section{DAFTAR PUSTAKA}

Agboyi LK, Ketoh GK, Martin T, Glitho IA, Tamo M. 2016. Pesticide resistance in Plutella xylostella (Lepidoptera: Plutellidae) populations from Togo and Benin. International Journal of Tropical Insect Science 36:204-210. doi: https:// doi.org/10.1017/S1742758416000138.

Ahmad B, Saljoqi AUR, Saeed M, Ullah F, Khan IA. 2015. Population dynamics of Plutella xylostella (L.) in cauliflower and its correlation with weather parameters at Peshawar, Pakistan. Journal of Entomology and Zoology Studies 3: 144-148

Clausen CP. 1940. Entomophagous Insects. New York: Mc. Graw-Hill Book Co.

Darmalis. 1994. Tingkat Konsumsi Makanan pada Larva Plutella xylostella (Lepidoptera: Yponomeutidae) Terparasit oleh Diadegma semiclausum Hellen (Hymenoptera: Ichneumonidae). Skripsi. Bogor: Institut Pertanian Bogor.

Dutcher JD. 2007. A review of resurgence and replacement causing pest outbreaks in IPM. In: Ciancio A, Mukerji K. G. (Eds.). General Concepts in Integrated Pest and Disease Management. Integrated Management of Plants Pests and Diseases. pp. 27-43. Springer: Dordrecht. doi: https://doi.org/10.1007/978-14020-6061-8_2.

Finney DJ. 1971. Probit Analysis. $3^{\text {rd }}$ Edition. Cambridge: Cambridge University Press.

Godfray HCJ. 1994. Parasitoids: Behavioral and Evolutionary Ecology. Princeton: Princeton Univ. Press.

Idris AB, Grafius E. 1993a. Field studies on the effect of pesticides on the diamondback moth (Lepidoptera: Plutellidae) and parasitism by Diadegma insulare (Hymenoptera: Ichneumonidae). Journal of Economic Entomology 86:11961202. doi: https://doi.org/10.1093/jee/86.4.1196. Idris AB, Grafius E. 1993b. Pesticides affect immature stages of Diadegma insulare (Hymenoptera: Ichneumonidae) and its host, the diamondback moth (Lepidoptera: Plutellidae). Journal of Economic Entomology 86:1203-1213. doi: https://doi.org/10.1093/jee/86.4.1203.

Iman M, Soekarna D, Situmorang J, Adiputra IMG, Manti I. 1986. Effect of insecticides on various field strains of diamondback moth and its parasitoid in Indonesia. In: Talekar NS, Griggs TD (Eds.). Diamondback Moth Management.

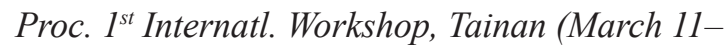
15 1985). pp. 313-323 Shanhua, Taiwan: VRDC.

Isman MB, Seffrin R. 2014. Natural insecticides from the Annonaceae: A unique example for developing biopesticides. In: Singh D. (Ed.), Advances in Plant Biopesticides. pp. 21-33. New Delhi: Springer. doi: https://doi.org/10.1007/97881-322-2006-0_2.

Kalshoven LGE. 1981. The Pests of Crops in Indonesia. Revised and translated by PA van der Laan. Jakarta: PT Ichtiar Baru-van Hoeve,

Lund RE. 1986. MSUSTAT Statistical Analysis Package: User's Guide. Montana: Research and Development Institute Inc., Montana State Univ. 
Mpumi N, Mtei K, Machunda R, Ndakidemi PA. 2016. The toxicity, persistence and mode of actions of selected botanical pesticides in Africa againts insect pests in common beans, $P$. vulgaris: A review. American Journal of Plant Sciences 7:138-151. doi: https://doi.org/10.4236/ ajps.2016.71015.

Oberemok VV, Laikova KV, Gninenko YI, Zaitsev AS, Nyadar PM, Adeyemi TA. 2015. A short history of insecticides. Journal of Plant Protection Research 55:221-226. doi: https://doi. org/10.1515/jppr-2015-0033.

Ohsawa K, Kato S, Manuwoto S. 1994. Bio-active substances from tropical plants. In: Sanches FF, Ohsawa K (eds.), Natural Bio-active Substances in Tropical Plants. pp. 65-72. Tokyo: NODAI Center for International Programs, Tokyo University of Agriculture.

Orr D. 2009. Biological control and integrated pest management. In: Peshin R, Dhawan AK (Eds.). Integrated Pest Management: InnovationDevelopment Procces. pp. 207-239. Dordrecht: Springer. doi: https://doi.org/10.1007/978-1-40208992-3 9.

Prijono D, Triwidodo H. 1994. Pemanfaatan insektisida nabati di tingkat petani. Di dalam: Prosiding Seminar Hasil Penelitian dalam Rangka Pemanfaatan Pestisida Nabati (Bogor, 1-2 Des. 1993). hlm. 76-83. Bogor: Balittro.

Rehman A, Powell W. 2010. Review: Host selection behaviour of aphid parasitoids (Aphididae: Hymenoptera). Journal of Plant Breeding and Crop Science 2:299-311

Rejesus BM. 1986. Botanical insecticides againts the diamondback moth. In: Talekar NS, Griggs TD (Eds.), Diamondback Moth Management. Proc.

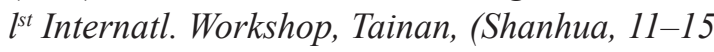
March 1985). pp. 241-255. Shanhua, Taiwan: AVRDC.

Sarfraz M, Keddie AB, Dosdal LM. 2005. Review: Biological control of the diamonback moth, Plutella xylostella: A review. Biocontrol Science and Technology 15:763-789. doi: https://doi. org/10.1080/09583150500136956.
Sastrosiswojo S, Sastrodihardjo S. 1986. Status of biological control of diamondback moth by introduction of parasitoid Diadegmaeucerophaga in Indonesia. In: Talekar NS, Griggs TD (Eds.), Diamondback Moth Management. Proc. $l^{\text {st }}$ Internatl. Workshop (Tainan, 11-15 March 1985. pp. 185-194. Shanhua, Taiwan: AVRDC.

Setiowati, B. 1995. Pengaruh Ekstrak Biji Srikaya (Annona squamosa L.) Terhadap Kematian Larva Spodoptera litura (F.) (Lepidoptera: Noctuidae) pada Lima Jenis Pakan. Skripsi. Bogor: Institut Pertanian Bogor.

Strand MR. 1988. Adaptive patterns of progeny and sex allocation by parasitic hymenoptera. In: In: Gupta V (Ed). Advances in Parasitic Hymenoptera Research. pp. 293-312. Amsterdam: E. J. Brill, Leiden.

Strand MR. 1990. The physiological interactions of parasitoids with their hosts and their influence on reproductive strategies. In: Waage J, Greathead D (Eds.), Insect Parasitoids. pp. 97-136. London: Academic Press.

Supriyanto. 1996. Pengaruh Ekstrak Biji Tujuh Jenis Tanaman Terhadap Mortalitas dan Perkembangan Crocidolomia Binotalis Zeller (Lepidoptera: Pyralidae). Skripsi. Bogor: Institut Pertanian Bogor.

van Alphen JJM, Vet LEM. 1990. An evolutionary approach to host finding and selection. In: Waage J, Greathead D (Eds.), Insect Parasitoids. pp. 23-61. London: Academic Press.

van den Bosch RPS, Messenger, Gutierrez AP. 1985. An Introduction to Biological Control. New York: Plenum Press.

Waage J. 1992. Quantifyng the impact of pesticides on natural enemies. In: Ooi PAC, Lim GS, Teng PS (Eds.), Biological Control: Issues in The Tropics. pp. 85-91. Taipei: AVRDC. 